\title{
Accumulation and export of nutrients in cactus pear cladodes (Opuntia ficus-indica) under different managements in the Brazilian Semiarid
}

\section{Marcos Neves Lopes ${ }^{1 *}$, Magno José Duarte Cândido', Walisson Marques Silveira² ${ }^{1}$, Theyson Duarte Maranhão ${ }^{3}$, Ismail Soares ${ }^{4}$, Roberto Cláudio Fernandes Franco Pompeu ${ }^{5}$, Rodrigo Gregório da Silva ${ }^{6}$, Maria Socorro de Souza Carneiro $^{1}$}

\author{
${ }^{1}$ Universidade Federal do Ceará, Departamento de Zootecnia, Fortaleza, CE, Brasil. \\ ${ }^{2}$ Universidade Federal do Ceará, Departamento de Engenharia Agrícola, Programa de Pós-graduação em Engenharia Agrícola, Fortaleza, CE, \\ Brasil. \\ ${ }^{3}$ Universidade Federal do Ceará, Departamento de Zootecnia, Programa de Pós-graduação em Zootecnia, Fortaleza, CE, Brasil. \\ ${ }^{4}$ Universidade Federal do Ceará, Departamento de Ciências do Solo, Fortaleza, CE, Brasil. \\ ${ }^{5}$ Empresa Brasileira de Pesquisa Agropecuária, Centro Nacional de Pesquisa Caprinos e Ovinos, Sobral, CE, Brasil. \\ ${ }^{6}$ Instituto Federal de Educação, Ciência e Tecnologia do Ceará, Campus Limoeiro do Norte, Limoeiro do Norte, CE, Brasil.
}

\begin{abstract}
The present study evaluated the accumulation and export of nutrients in cactus pear (Opuntia ficus-indica) cv. Gigante, fertilized with combinations of nitrogen $\left(10,70,100,130\right.$, and $\left.190 \mathrm{~kg} \mathrm{ha}^{-1} \mathrm{year}^{-1} \mathrm{~N}\right)$ and phosphorus $(10,70$, 100, 130 , and $190 \mathrm{~kg} \mathrm{ha}^{-1}$ year ${ }^{-1} \mathrm{P}_{2} \mathrm{O}_{5}$ ) under annual and biennial harvests, in Quixadá and Tejuçuoca, using a split-plot randomized block design with four replications. In Quixadá, under annual and biennial harvests, the following orders of accumulation of macronutrients (in $\mathrm{kg} \mathrm{ha}^{-1}$ year $^{-1}$ ) were found, respectively: $\mathrm{K}(98.8)>\mathrm{Ca}(87.2)>\mathrm{N}(46.7)>\mathrm{Mg}(26.8)>\mathrm{S}(18.4)>\mathrm{P}(2.04)$ and $\mathrm{Ca}(33.5)>\mathrm{K}(31.1)>\mathrm{S}(18.6)>\mathrm{N}(12.9)>\mathrm{Mg}(10.5)>\mathrm{P}(0.81)$. In Tejuçuoca, under annual and biennial harvests, the orders of accumulation of macronutrients were, respectively: $\mathrm{K}(146.5)>\mathrm{Ca}(204.6)>\mathrm{N}(128.1)>\mathrm{Mg}(75.8)>\mathrm{S}(50.3)>\mathrm{P}(3.7)$ and $\mathrm{K}(397.2)>\mathrm{N}(191.3)>\mathrm{S}(241.2)>\mathrm{Ca}(167.8)>\mathrm{Mg}(131.0)>\mathrm{P}(14.1)$. The maintenance/production fertilization in cactus pear should be planned according to productive potential, fertilization and harvest managements, and cultivation region, based on nutritional requirement and considering the nutrient recovery efficiency.
\end{abstract}

Key Words: fertilization, harvest frequency, nutritional demand

\section{Introduction}

The knowledge of nutritional requirement of cactus pear from the quantification of nutrient extraction is essential, since its output from the soil system during successive production cycles may reflect in a decrease of crop productivity in the absence of a balanced replenishment of nutrients exported with the harvest (Nobel et al., 1987; Alves et al., 2007; Dubeux Jr. et al., 2010). Evaluating the accumulation and export of nutrients in cactus pear represents a relevant starting point in the definition of levels of fertilizers to be used, constituting a necessary step in the maintenance of adequate nutrition of

Received: March 15, 2017

Accepted: November 8, 2017

*Corresponding author: nevesvv@yahoo.com.br

Copyright (C) 2018 Sociedade Brasileira de Zootecnia. This is an Open Access article distributed under the terms of the Creative Commons Attribution License (http://creativecommons.org/licenses/by/4.0/), which permits unrestricted use, distribution, and reproduction in any medium, provided the original work is properly cited. the crop (Dubeux Jr. et al., 2010; Silva et al., 2012), with monitoring of the balance between the input and output of nutrients in the system, aiming at improvements in soil fertility over the years of cultivation (Nobel et al., 1987).

The high potential for nutrient extraction in cactus pear is evident in studies about the topic, which have shown quantitative changes in response to the different fertilization managements (Dubeux Jr. et al., 2010; Silva et al., 2012), frequency and intensity of harvests (Alves et al., 2007), plant spacing and density (Silva et al., 2012; Cavalcante et al., 2014), cultivated species/cultivar (Cavalcante et al., 2014), and soil and climatic conditions for cultivation (Nobel et al., 1987).

When evaluating the cactus pear clone IPA-20 subjected to four levels of phosphorus $\left(0,200,400\right.$, and $800 \mathrm{~kg} \mathrm{ha}^{-1}$ $\left.\mathrm{P}_{2} \mathrm{O}_{5}\right)$ and four levels of potassium $(0,200,400$, and 800 $\mathrm{kg} \mathrm{ha}^{-1} \mathrm{~K}_{2} \mathrm{O}$ ), Dubeux Jr. et al. (2010) observed a variation in the accumulation of macro- and micronutrients caused by fertilization. In research with cactus pear cv. Gigante managed under three spacings and different fertilizations (P, NP, and NPK), Silva et al. (2012) observed that, 620 days 
after sowing, the most extracted macronutrient was calcium, with $458.3 \mathrm{~kg} \mathrm{ha}^{-1}$, followed by potassium $\left(425.8 \mathrm{~kg} \mathrm{ha}^{-1}\right)$, nitrogen $\left(299.3 \mathrm{~kg} \mathrm{ha}^{-1}\right)$, magnesium $\left(213.8 \mathrm{~kg} \mathrm{ha}^{-1}\right)$, sulfur $\left(63.3 \mathrm{~kg} \mathrm{ha}^{-1}\right)$, and phosphorus (20.3 $\left.\mathrm{kg} \mathrm{ha}^{-1}\right)$.

In this context, the nutrient accumulation in cactus pear, which reflects the nutritional requirement of this crop, varies according to factors such as species/cultivar, level of biomass production, soil fertility, fertilization management, climate, harvest frequency, and cultural practices. However, the magnitude of the responses is diverse, which justify the demand for research aimed at quantifying the nutritional needs of cactus pear in terms of nutrients accumulated and exported in the harvest.

Therefore, this research was developed from the hypothesis that there is a balanced combination of nitrogenphosphorus-harvest frequency (N-P-HF) that promotes the maximization of the accumulation and export of macronutrients in cactus pear cv. Gigante under different environmental conditions. In view of the above, this study was conducted to evaluate the nutrient accumulation and export in cactus pear cv. Gigante, fertilized with different combinations of $\mathrm{N}$ and $\mathrm{P}$ under two harvest frequencies, in the semi-arid regions of Quixadá and Tejuçuoca, state of Ceará, Brazil.

\section{Material and Methods}

The experiment was conducted in Quixadá and Tejuçuoca, Ceará, Brazil. The experimental area in Quixadá is located at $190 \mathrm{~m}$ altitude, at the geographical coordinates: $4^{\circ} 59^{\prime} \mathrm{S}$ latitude and $39^{\circ} 01^{\prime} \mathrm{W}$ longitude, with a BSw'h' hot semi-arid climate, according to Köppen classification (1948). Tejuçuoca is located at an average altitude of $140 \mathrm{~m}$, at the following geographical coordinates: $3^{\circ} 59^{\prime} 11^{\prime \prime S}$ latitude and $39^{\circ} 34^{\prime} 18^{\prime \prime} \mathrm{W}$ longitude, with Aw climate, tropical with dry season, according to Köppen classification (1948).

The average temperature and relative air humidity of the experimental period and the cumulative annual rainfall were recorded in both regions: in Quixadá, values of $27.0^{\circ} \mathrm{C}$ and $58.8 \%$ were recorded for temperature and relative air humidity, respectively, in the experimental period; rainfall values of 1,042 and $602 \mathrm{~mm}$ were verified in 2011 and 2012, respectively. In Tejuçuoca, the values were $26.4{ }^{\circ} \mathrm{C}$ and $65.5 \%$ for temperature and relative air humidity, respectively; rainfall values were 1,038 and $561 \mathrm{~mm}$ in 2011 and 2012, respectively. Data were obtained at the Agroclimatological Station of the Universidade Federal do Ceará (Quixadá) and at the Agroclimatological Station of FUNCEME
(Tejuçuoca). In both regions, the study started in 2011 and was similar regarding treatments.

The physical and chemical characterization of soils, in both regions, was performed at the layer $0.0-20.0 \mathrm{~cm}$. The soil texture was classified as sandy in Quixadá and sandy loam in Tejuçuoca. In Quixadá, the samples had the following composition: $5 \mathrm{mg} \mathrm{dm}^{-3} \mathrm{P} ; 260 \mathrm{mg} \mathrm{dm}^{-3} \mathrm{~K}$; $20 \mathrm{mg} \mathrm{dm} \mathrm{Na}^{-3} ; 3.4 \mathrm{cmol}_{\mathrm{c}} \mathrm{dm}^{-3} \mathrm{Ca}^{2+} ; 3.4 \mathrm{cmol}_{\mathrm{c}} \mathrm{dm}^{-3} \mathrm{Mg}^{2+}$; $0.0 \mathrm{cmol}_{\mathrm{c}} \mathrm{dm}^{-3} \mathrm{Al}^{3+} ; 5.3 \mathrm{~g} \mathrm{~kg}^{-1}$ organic matter; sum of bases: $7.6 \mathrm{cmol}_{\mathrm{c}} \mathrm{dm}^{-3}$; CTCt: $7.6 \mathrm{cmol}_{\mathrm{c}} \mathrm{dm}^{-3}$; pH of 6.1 in water; coarse sand: $513 \mathrm{~g} \mathrm{~kg}^{-1}$; fine sand: $363 \mathrm{~g} \mathrm{~kg}^{-1}$; silt: $89 \mathrm{~g} \mathrm{~kg}^{-1}$, and clay: $35 \mathrm{~g} \mathrm{~kg}^{-1}$. In Tejuçuoca, the following composition was found: $6 \mathrm{mg} \mathrm{dm}{ }^{-3} \mathrm{P} ; 243 \mathrm{mg} \mathrm{dm}{ }^{-3} \mathrm{~K} ; 7 \mathrm{mg} \mathrm{dm}^{-3} \mathrm{Na}^{+}$; $4.0 \mathrm{cmol}_{\mathrm{c}} \mathrm{dm}^{-3} \mathrm{Ca}^{2+} ; 3.2 \mathrm{cmol}_{\mathrm{c}} \mathrm{dm}^{-3} \mathrm{Mg}^{2+} ; 0.0 \mathrm{cmol}_{\mathrm{c}} \mathrm{dm}^{-3}$ $\mathrm{Al}^{3+} ; 8.2 \mathrm{~g} \mathrm{~kg}^{-1}$ organic matter; sum of bases: $7.9 \mathrm{cmol}_{\mathrm{c}} \mathrm{dm}^{-3}$; CTCt: $7.9 \mathrm{cmol}_{\mathrm{c}} \mathrm{dm}^{-3}$; $\mathrm{pH}$ of 6.2 in water; coarse sand: $164 \mathrm{~g} \mathrm{~kg}^{-1}$; fine sand: $590 \mathrm{~g} \mathrm{~kg}^{-1}$; silt: $153 \mathrm{~g} \mathrm{~kg}^{-1}$, and clay: $93 \mathrm{~g} \mathrm{~kg}^{-1}$.

Soil was prepared for cactus pear (Opuntia ficus-indica cv. Gigante) planting following these steps: removal of stumps (whenever necessary), removal of vegetation from the area, and harrowing. Subsequently, the plots were marked for delimitation of the respective area. Each plot occupied an area of $24.0 \mathrm{~m}^{2}(4.0 \times 6.0 \mathrm{~m})$, which was composed of 120 plants, distributed in three rows of $4.0 \mathrm{~m}$ in length - the central row was used for measurements and the others as borders.

After harvesting, the cladodes were allowed to rest in the shade for 15 days (Lopes et al., 2009) to heal injuries caused during harvesting and transportation.

Furrows were made by hand using cutter mattock, narrow hoe, and hoe, obeying the average depth of $30 \mathrm{~cm}$ and spacing of $2.0 \mathrm{~m}$. Cladodes were inserted up to the depth that provided the coverage of $2 / 3$ of their length, at $2.0 \times 0.10 \mathrm{~m}$ spacing, recommended to meet the density of 50,000 plants $\mathrm{ha}^{-1}$.

Nine combinations of $\mathrm{N}$ and $\mathrm{P}_{2} \mathrm{O}_{5}$ levels, consisting of five levels of $\mathrm{N}\left(10,70,100,130\right.$, and $190 \mathrm{~kg} \mathrm{ha}^{-1}$ year $\left.^{-1}\right)$ as urea and five levels of $\mathrm{P}_{2} \mathrm{O}_{5}(10,70,100,130$, and 190 $\mathrm{kg} \mathrm{ha}^{-1}$ year $^{-1}$ ) as single superphosphate, according to the matrix Plan Puebla II, for two factors $\left(2^{k}+2 k+1\right)$ were examined. We adopted a standard combination (central point) of $\mathrm{N}\left(100 \mathrm{~kg} \mathrm{ha}^{-1}\right.$ year $\left.^{-1}\right)$ and $\mathrm{P}_{2} \mathrm{O}_{5}\left(100 \mathrm{~kg} \mathrm{ha}^{-1}\right.$ year $^{-1}$ ) and from this, the other combinations were defined according to fixed levels of $\pm 0.3(30 \%)$ and \pm 0.9 (90\%) (Table 1).

The nine combinations of $\mathrm{N}$ and $\mathrm{P}$ were studied in association with two harvesting frequencies (annual and biennial) of cactus pear, totaling 18 treatments (Table 1), 
with four replications, distributed in a split-plot completely randomized block design, with combinations of $\mathrm{N}$ and $\mathrm{P}_{2} \mathrm{O}_{5}$ levels assigned to the plots and the harvest frequencies, to the subplots (Figures 1 and 2).

Fertilization was performed during the rainy season. The annual level of $P$, as single superphosphate, was made

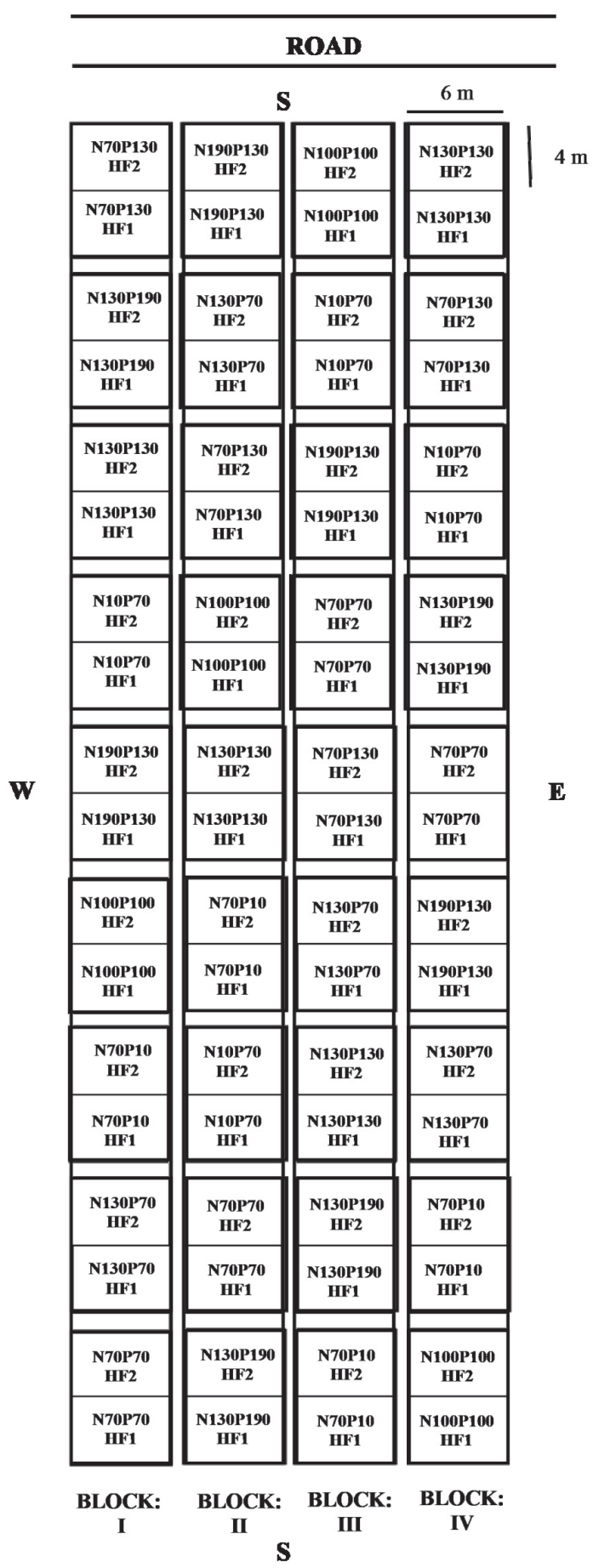

$\mathrm{N}$ - Nitrogen; P - phosphorus; HF - harvest frequency

Figure 1 - Experiment layout on semiarid conditions of Quixadá. available at once, upon planting for the first year and when the rainy season began, for the other years of cultivation. At this time, the micronutrients were applied at $50 \mathrm{~kg} \mathrm{ha}^{-1}$ FTE BR-12. Calcium and S balancing was performed for all treatments using agricultural gypsum and calcitic limestone based on the highest level of single superphosphate.

Table 1 - Treatments studied under the semiarid conditions of Quixadá and Tejuçuoca

\begin{tabular}{lc}
\hline $\mathrm{N}_{2}$ and $\mathrm{P}_{2} \mathrm{O}_{5}\left(\mathrm{~kg} \mathrm{ha}^{-1}\right.$ year $\left.^{-1}\right)$ & Harvest frequency \\
\hline 10 and 70 & Annual \\
10 and 70 & Biennial \\
70 and 10 & Annual \\
70 and 10 & Biennial \\
70 and 70 & Annual \\
70 and 70 & Biennial \\
70 and 130 & Annual \\
70 and 130 & Biennial \\
100 and 100 & Annual \\
100 and 100 & Biennial \\
130 and 70 & Annual \\
130 and 70 & Biennial \\
130 and 130 & Annual \\
130 and 130 & Biennial \\
130 and 190 & Annual \\
130 and 190 & Biennial \\
190 and 130 & Annual \\
190 and 130 & Biennial \\
\hline
\end{tabular}

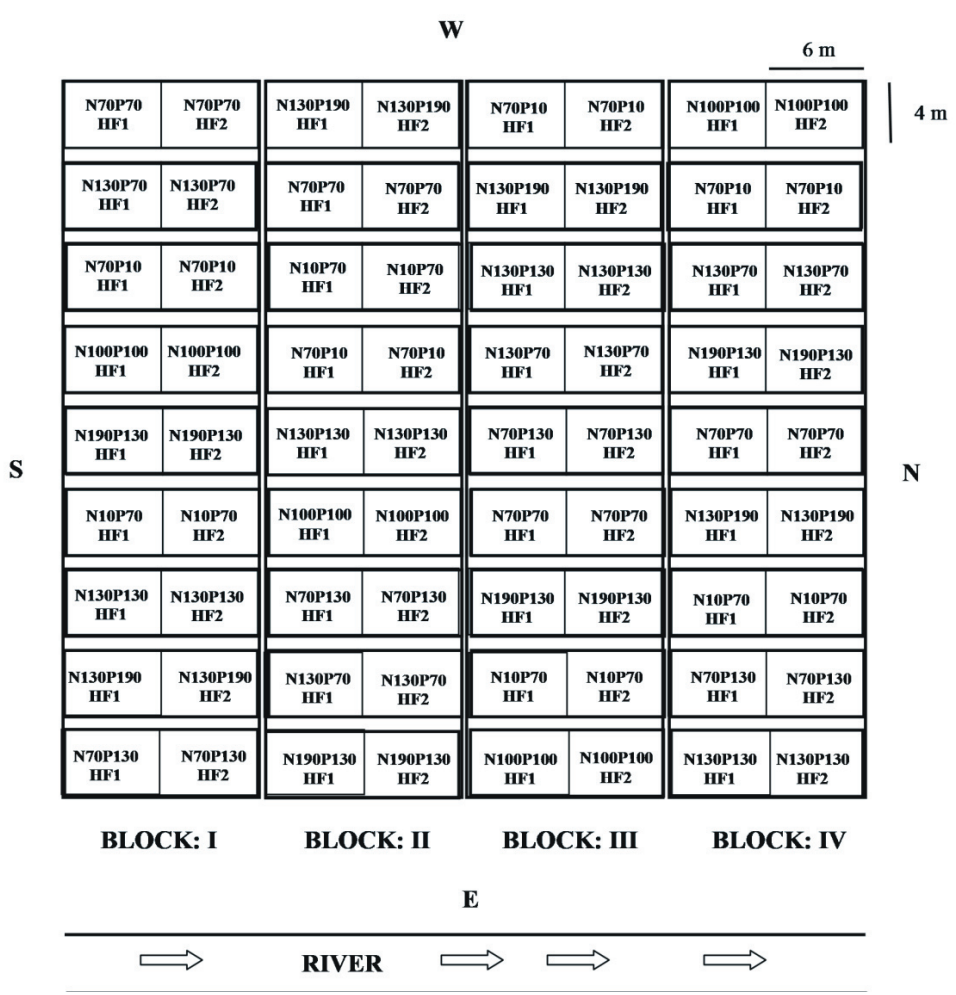

$\mathrm{N}$ - Nitrogen; P - phosphorus; HF - harvest frequency.

Figure 2 - Experiment layout on semiarid conditions of Tejuçuoca. 
The annual level of $\mathrm{N}$, as urea, was made available in three plots, with a 20-day interval between applications. In all applications, urea was diluted in water, by applying $1 \mathrm{~L}$ solution to each 4-m length of the cactus pear row, totaling the volume of $3 \mathrm{~L}$ per plot. Dilution was carried out to obtain a better uniformity of application, due to the small amount of fertilizer per plot in some levels, making it difficult to apply in solid form. Weed control was made with cleaning and herbicide application in directed jet. The control of cochineal (Diaspis echinocacti) was carried out using mineral oil.

Samples were subjected to chemical analysis to determine the content of $\mathrm{N}, \mathrm{P}, \mathrm{K}, \mathrm{Ca}, \mathrm{Mg}$, and $\mathrm{S}$, according to Silva (2009). The accumulated (total biomass) and exported (harvested biomass) macronutrients (N, P, K, Ca, $\mathrm{Mg}$, and $\mathrm{S}$ ) in the cactus pear biomass were determined by multiplying the respective nutrient contents in the cladode tissues by the production of the crop expressed in $\mathrm{kg} \mathrm{ha}^{-1}$ year $^{-1}$.

In the determination of total forage biomass (TFB, $\mathrm{kg} \mathrm{ha}^{-1}$ year $^{-1}$ ), the sum of biomass production of all cladode orders was considered. In the determination of harvested forage biomass (HFB, $\mathrm{kg} \mathrm{ha}^{-1}$ year $^{-1}$ ), the production above cut height was considered, which represents harvested biomass with preservation of primary cladodes.

The statistical model used in the experiment was the following:

$$
\mathrm{y}_{\mathrm{ijk}}=\mu+\beta_{\mathrm{k}}+\alpha_{\mathrm{i}}+(\alpha \beta)_{\mathrm{ik}}+\tau_{\mathrm{j}}+(\alpha \tau)_{\mathrm{ij}}+\varepsilon_{\mathrm{ijk}},
$$

in which $\mathrm{y}_{\mathrm{ijk}}=$ value observed in experimental plot that received level $i$ of factor $\alpha$ (fertilization) and level $j$ of factor $\tau$ (harvest frequency) in block $k ; \mu=$ general constant; $\beta_{\mathrm{k}}=$ block effect $k\left(k=1,2,3\right.$, and 4); $\alpha_{\mathrm{i}}=$ effect of level $i$ of factor $\alpha(i=1,2,3,4,5,6,7,8$, and 9$) ;(\alpha \beta)_{\text {ik }}=$ effect of the interaction between level $i$ of factor $\alpha$ and block $k$ (error a); $\tau_{\mathrm{j}}=$ effect of level $j$ of factor $\tau(j=1$ and 2$) ;(\alpha \tau)_{\mathrm{ij}}=$ effect of the interaction between level $i$ of factor $\alpha$ and level $j$ of factor $\tau$; and $\varepsilon_{\mathrm{ijk}}=$ experimental error (error b).

Data were tested by analysis of variance, comparison of means, and multiple regression models. Qualitative factors were compared by the Scott-Knott comparison test at 5\% probability level. Quantitative factors were studied in multiple regression models (up to the $10 \%$ probability level). The software System for Statistical and Genetic Analysis (SAEG 9.1, 2007) was used as a tool to aid analysis.

\section{Results}

The combinations of $\mathrm{N}$ and $\mathrm{P} \times$ harvest frequencies had an effect on the accumulation and export of macronutrients in Quixadá and Tejuçuoca. When evaluated, the accumulation and export of $\mathrm{N}, \mathrm{P}, \mathrm{K}, \mathrm{Ca}$, $\mathrm{Mg}$, and $\mathrm{S}$ in cactus pear under annual and biennial harvest frequencies in Quixadá and Tejuçuoca showed an effect of $\mathrm{N}$ and $\mathrm{P}$ combinations (Tables 2, 3, and 4), fitting to a multiple regression model.

In Quixadá, for all combinations of $\mathrm{N}$ and $\mathrm{P}$, there was a higher accumulation and export of $\mathrm{N}$ under the annual harvest (Table 5). In Tejuçuoca, there was a higher accumulation and export of $\mathrm{N}$ under the biennial harvest in most combinations of $\mathrm{N}$ and $\mathrm{P}$ (Table 6).

In Quixadá, accumulation and export of $\mathrm{P}$ under the annual harvest were higher than those of the biennial harvest for all combinations of $\mathrm{N}$ and $\mathrm{P}$ (Table 5). In Tejuçuoca, $\mathrm{P}$ accumulation was higher under the biennial harvest for five combinations of $\mathrm{N}$ and $\mathrm{P}$ and the export, for six combinations, in relation to the annual harvest (Table 6).

In Quixadá, there was a higher accumulation and export of $\mathrm{K}$ under the annual harvest for all combinations of $\mathrm{N}$ and P levels (Table 5). In Tejuçuoca, there was a greater $\mathrm{K}$ accumulation under the biennial crop in six combinations of $\mathrm{N}$ and $\mathrm{P}$. The $\mathrm{P}$ export was higher under the biennial harvest in $88.9 \%$ of the $\mathrm{N}$ and $\mathrm{P}$ combinations (Table 6).

In Quixadá, the accumulation and export of $\mathrm{Ca}$ for all combinations of $\mathrm{N}$ and $\mathrm{P}$ (Table 5) was higher under the annual harvest. In Tejuçuoca, $\mathrm{Ca}$ accumulation was higher under the annual harvest for six combinations of $\mathrm{N}$ and $\mathrm{P}$ levels. A higher $\mathrm{Ca}$ export under the biennial harvest was verified for five combinations of $\mathrm{N}$ and $\mathrm{P}$ (Table 6).

In Quixadá, higher accumulation and export of $\mathrm{Mg}$ were observed under the annual harvest for all combinations of $\mathrm{N}$ and $\mathrm{P}$ (Table 5). In Tejuçuoca, there was a superiority in the $\mathrm{Mg}$ accumulation under the biennial harvest in almost all combinations of $\mathrm{N}$ and $\mathrm{P}$. We observed a higher $\mathrm{Mg}$ export under the biennial crop for all combinations of $\mathrm{N}$ and $\mathrm{P}$ (Table 6).

In Quixadá, $\mathrm{S}$ accumulation was higher under the annual harvest for six combinations of $\mathrm{N}$ and $\mathrm{P}$. A higher $S$ export was found under the biennial crop for $66.7 \%$ of the $\mathrm{N}$ and $\mathrm{P}$ combinations (Table 5). In Tejuçuoca, higher accumulation and export of $\mathrm{S}$ were observed under the biennial harvest for most of the combinations of $\mathrm{N}$ and $\mathrm{P}$ (Table 6).

\section{Discussion}

The effect of $\mathrm{N}$ and $\mathrm{P}$ fertilization on the accumulation and export of $\mathrm{N}$ under the different harvest managements is a result of the activity of these nutrients in the production of 
forage biomass, since the total extraction is dependent on the biomass yield and nutrient content in plant tissues.

In both harvest frequencies, the addition of $\mathrm{N}$ increased the content and availability of this nutrient in the soil solution (Costa et al., 2008), which favored higher uptake of the nutrient, resulting in increased biomass and, consequently, increase in the accumulation and export of this nutrient with the harvest. In Quixadá, under annual harvest, the combination of $\mathrm{N}$ and $\mathrm{P}$ had a positive effect on the accumulation and export of $\mathrm{N}$. This is a result of the higher $\mathrm{N}$ influx, increasing its uptake and, consequently, the accumulation.
In both regions, for the conditions in which there was an increase in the accumulation and export of $\mathrm{N}$ with the addition of $\mathrm{P}$, this increase was due to the effect of this nutrient (P) on growth, development (Malavolta et al., 2006), and increase in root biomass (Souto et al., 2009; Bonfim-Silva et al., 2011; Bonfim-Silva et al., 2014), improving the uptake and consequently the accumulation and export of nitrogen.

In the two regions, the distinct response pattern for the accumulation and export of $\mathrm{P}$, as a function of the combinations of $\mathrm{N}$ and $\mathrm{P}$ under annual and biennial harvest frequencies, is a result of the structural consolidation of the crop, combined with environmental factors. In this context,

Table 2 - Accumulation and export of nitrogen and phosphorus in response to combinations of $\mathrm{N}$ and $\mathrm{P}$ levels in cactus pear, in the regions of Quixadá and Tejuçuoca

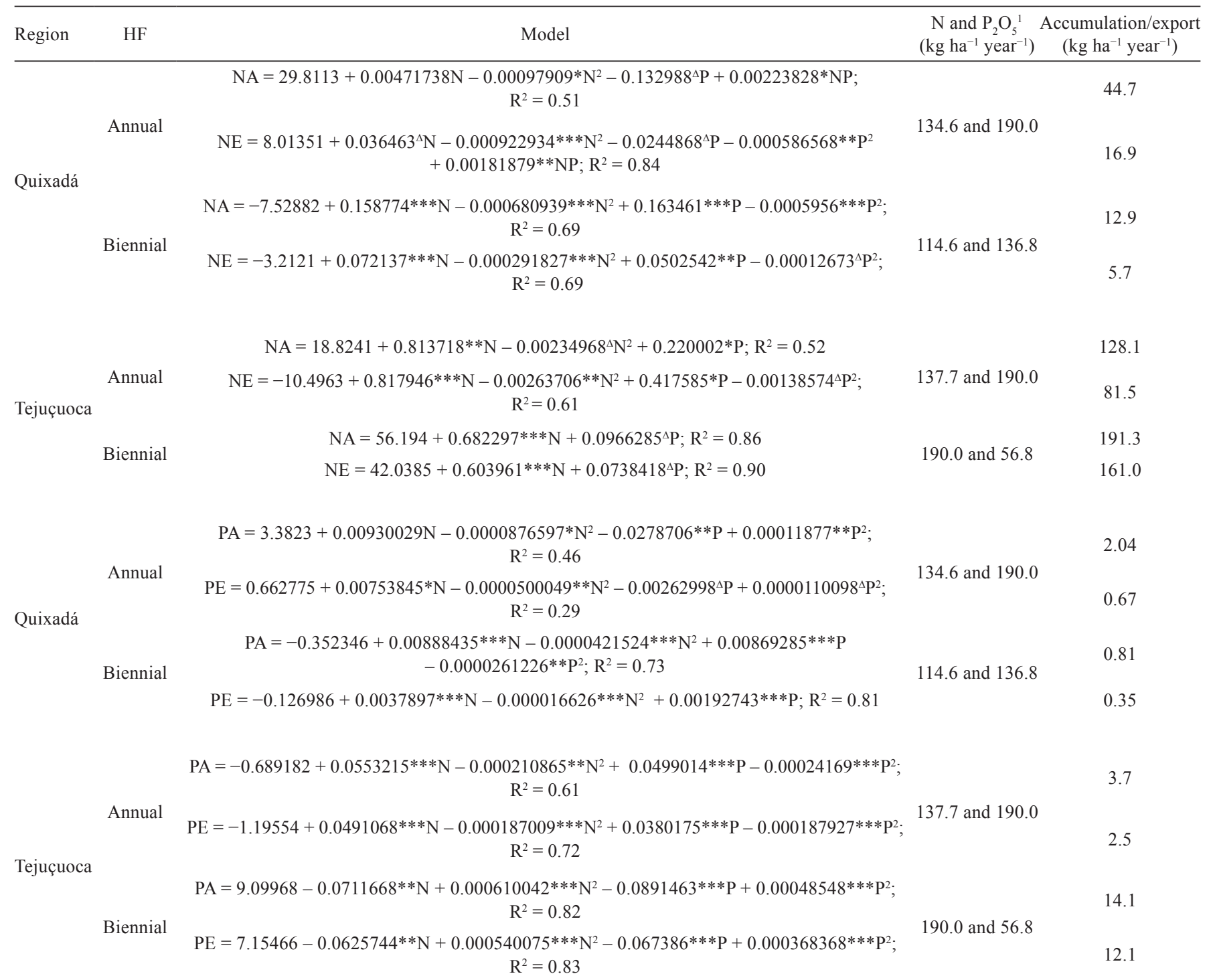

HF - harvest frequency; NA - nitrogen accumulation; NE - nitrogen export; PA - phosphorus accumulation; PE - phosphorus export; $\mathrm{R}^{2}$ - coefficient of determination.

${ }^{1}$ Combined levels of $\mathrm{N}$ and $\mathrm{P}$ for maximum production of cactus pear biomass [3522.9 and $1583.2 \mathrm{~kg} \mathrm{ha}^{-1}$ year $^{-1}$ (Quixadá) and 9783.0 and $12124.0 \mathrm{~kg}^{-1}$ year ${ }^{-1}$ (Tejuçuoca) on annual and biennial harvests, respectively].

$* * *$ Significant at $0.1 \%$ probability.

** Significant at $1 \%$ probability.

* Significant at $5 \%$ probability.

$\Delta$ Significant at $10 \%$ probability. 
it is worth emphasizing that, under the annual harvest, the crop was subjected to more stressful management conditions due to frequent cuts. This led to varied responses in $\mathrm{P}$ accumulation, reflecting the differentiated potential of the crop in responding to the applied nutrients.

Nitrogen, while governed by mass flow transport, had an influence on the accumulation and export of $\mathrm{P}$ from the lowest $\mathrm{N}$ levels under annual (Quixadá and Tejuçuoca) and biennial (Quixadá) harvest frequencies until reaching the maximum with higher levels. Under certain conditions, from higher levels, phosphate fertilization increased the accumulation and export of $\mathrm{P}$, which can be ascribed to the effect of the phosphate fertilizer at the highest levels, by increasing the passage of the nutrient to a labile form, favoring the availability to the crop, promoting greater uptake, and, consequently, increasing the extraction.

In Tejuçuoca, the accumulation and export of $\mathrm{P}$ were increased from low combined levels of $\mathrm{N}$ and $\mathrm{P}$ under annual harvest frequency. This response can be attributed to the lower competition between plants, reflecting the

Table 3 - Accumulation and export of potassium and calcium in response to combinations of levels of $\mathrm{N}$ and P in cactus pear, in Quixadá and Tejuçuoca

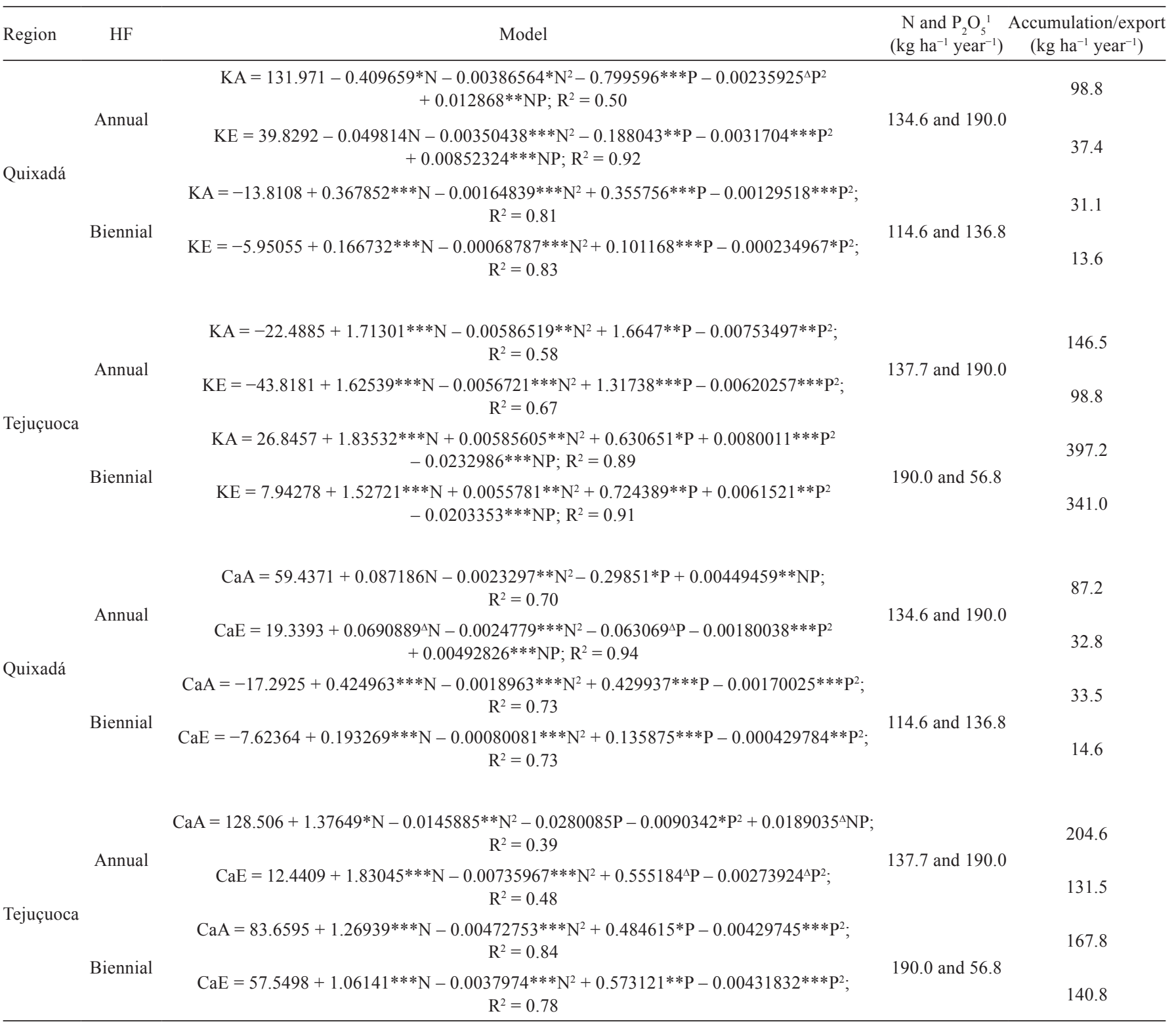

$\mathrm{HF}$ - harvest frequency; KA - potassium accumulation; KE - potassium export; CaA - calcium accumulation; CaE - calcium export; $\mathrm{R}^{2}$ - coefficient of determination.

${ }^{1}$ Combined levels of $\mathrm{N}$ and $\mathrm{P}$ for maximum production of cactus pear biomass [3522.9 and $1583.2 \mathrm{~kg} \mathrm{ha}^{-1}$ year $^{-1}$ (Quixadá) and 9783.0 and $12124.0 \mathrm{~kg} \mathrm{ha}^{-1}$ year ${ }^{-1}$ (Tejuçuoca) on annual and biennial harvests, respectively].

*** Significant at $0.1 \%$ probability.

$* *$ Significant at $1 \%$ probability.

* Significant at $5 \%$ probability.

$\Delta$ Significant at $10 \%$ probability. 
reduction of the stand with the cultivation time in the cactus pear under annual cut. In turn, under the biennial management, there was an increase in the accumulation and export of $\mathrm{P}$ in the higher combinations of $\mathrm{N}$ and $\mathrm{P}$, which reflects the higher nutritional demand of the forage under the said management conditions, in response to the crop with greater density of plants. In the two conditions of the study, but mainly in Quixadá, small amounts of extracted/ exported $\mathrm{P}$ were observed, indicating the low nutrient recovery applied through fertilization.
In Quixadá, under annual harvest, with lower combinations of $\mathrm{N}$ and $\mathrm{P}$, there were declines in the accumulation and export of $\mathrm{K}$. However, the synergistic effect between $\mathrm{N}$ and $\mathrm{P}$ may have favored the uptake of both (Silva et al., 2012), since they can present transport by symport, in which the two ions of opposite signs $\left(\mathrm{NH}_{4}^{+}\right.$and $\mathrm{H}_{2} \mathrm{PO}_{4}^{-}$) are absorbed together.

Under the biennial harvest in Quixadá, with the lowest combinations of $\mathrm{N}$ and $\mathrm{P}$ levels, there were increases in the accumulation and export of K. At 730 days after planting,

Table 4 - Accumulation and export of magnesium and sulfur in response to combinations of levels of $\mathrm{N}$ and $\mathrm{P}$ in cactus pear, in the regions of Quixadá and Tejuçuoca

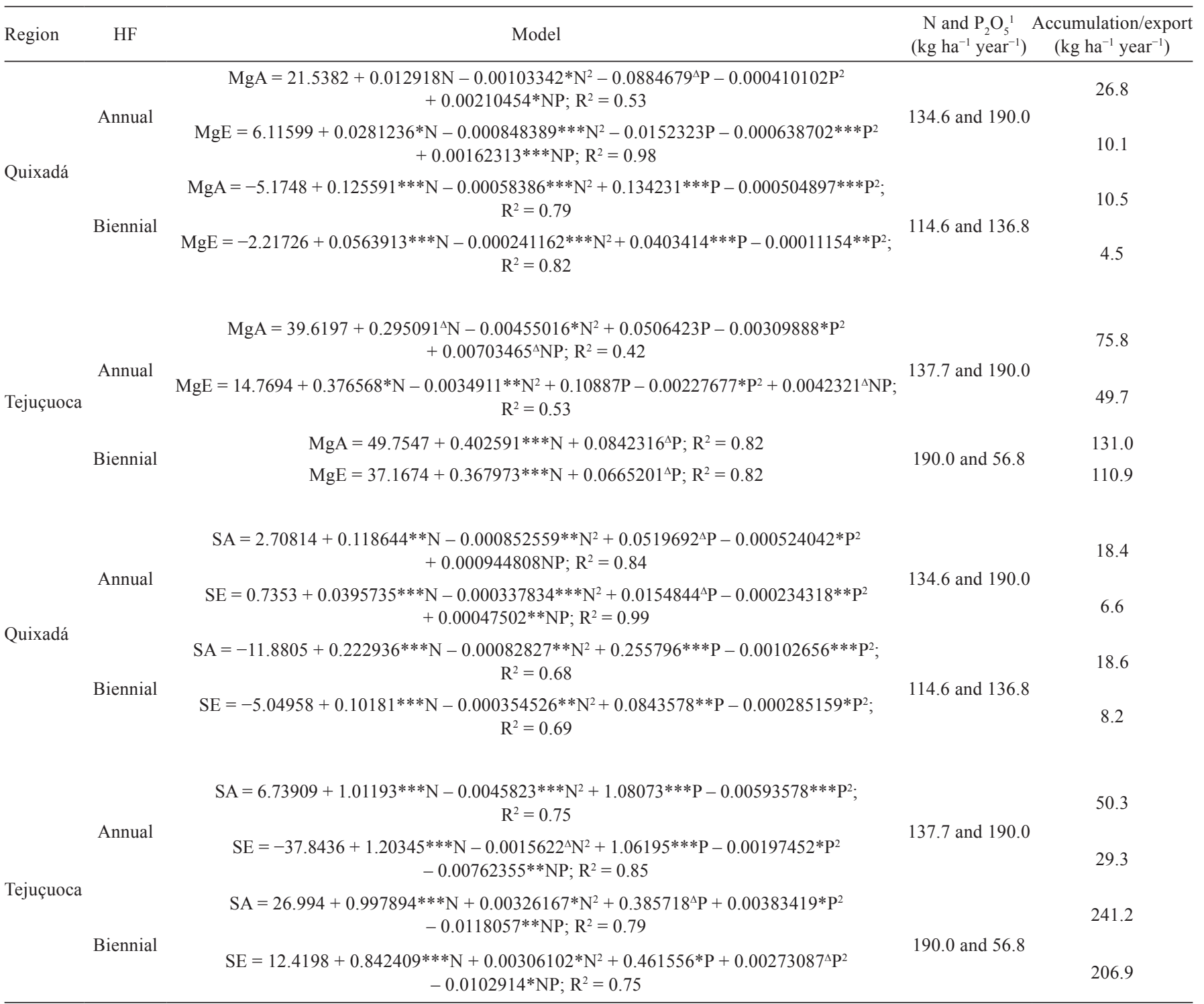

$\mathrm{HF}$ - harvest frequency; MgA - magnesium accumulation; MgE - magnesium export; SA - sulfur accumulation; SE - sulfur export; $\mathrm{R}^{2}$ - coefficient of determination.

${ }^{1}$ Combined levels of $\mathrm{N}$ and $\mathrm{P}$ for maximum production of cactus pear biomass [3522.9 and $1583.2 \mathrm{~kg} \mathrm{ha}^{-1}$ year $^{-1}$ (Quixadá) and 9783.0 and $12124.0 \mathrm{~kg} \mathrm{ha}^{-1}$ year ${ }^{-1}$ (Tejuçuoca) on annual and biennial harvests, respectively].

*** Significant at $0.1 \%$ probability.

** Significant at $1 \%$ probability.

* Significant at $5 \%$ probability.

$\Delta$ Significant at $10 \%$ probability. 
plants probably showed a greater growth of the root system and, consequently, a smaller distance between ion and root, favoring the contact by diffusion, potentiating $\mathrm{K}^{+}$uptake and its accumulation/export in response to fertilization. In the two regions, the increases observed in the accumulation and export of $\mathrm{K}$ according to the $\mathrm{N}$ and $\mathrm{P}$ combinations are a result of the effect of nutrients on the morphological and physiological characteristics of the cactus pear, which resulted in a greater total biomass accumulation.

In Quixadá and Tejuçuoca, the accumulation and export of $\mathrm{Ca}$ as a function of the $\mathrm{N}$ and $\mathrm{P}$ combinations under the two harvest frequencies reflected the effect of nutrition on productivity. The performance of $\mathrm{N}$ in the accumulation and export of $\mathrm{Ca}$ under the annual and biennial harvest management can be attributed to the increased biomass, associated with the increase in nitrate content in the plant tissue, which increases the uptake of cations, such as $\mathrm{Ca}^{2+}$, to maintain the cation-anion balance in the plant (Mengel and Kirkby, 2001).

In both study regions, in the management with annual harvest, the combination of $\mathrm{N}$ and $\mathrm{P}$ favored $\mathrm{Ca}$ extraction at the highest levels of fertilization. The decreasing effect

Table 5 - Accumulation and export of macronutrients by cactus pear according to harvest frequencies, for different combinations of nitrogen and phosphorus, in the region of Quixadá

\begin{tabular}{|c|c|c|c|c|c|c|c|c|c|}
\hline \multirow{2}{*}{$\mathrm{HF}$} & \multicolumn{9}{|c|}{ Combinations of $\mathrm{N}$ and $\mathrm{P}_{2} \mathrm{O}_{5}\left(\mathrm{~kg} \mathrm{ha}^{-1}\right.$ year $\left.^{-1}\right)$} \\
\hline & $10 / 70$ & $70 / 10$ & $70 / 70$ & $70 / 130$ & $100 / 100$ & $130 / 70$ & $130 / 130$ & $130 / 190$ & $190 / 130$ \\
\hline \multicolumn{10}{|c|}{ Nitrogen accumulation $\left(\mathrm{kg} \mathrm{ha}^{-1}\right.$ year $\left.^{-1} ; \mathrm{CV}=16.8 \%\right)$} \\
\hline Annual & $22.9 \mathrm{~A}$ & $26.7 \mathrm{~A}$ & $19.4 \mathrm{~A}$ & $26.8 \mathrm{~A}$ & $44.0 \mathrm{~A}$ & $23.4 \mathrm{~A}$ & $26.7 \mathrm{~A}$ & $45.1 \mathrm{~A}$ & $34.2 \mathrm{~A}$ \\
\hline Biennial & $2.1 \mathrm{~B}$ & $3.3 \mathrm{~B}$ & $6.1 \mathrm{~B}$ & $11.6 \mathrm{~B}$ & $17.7 \mathrm{~B}$ & $6.6 \mathrm{~B}$ & $11.7 \mathrm{~B}$ & $10.4 \mathrm{~B}$ & $10.3 \mathrm{~B}$ \\
\hline \multicolumn{10}{|c|}{ Nitrogen export $\left(\mathrm{kg} \mathrm{ha}^{-1}\right.$ year $\left.^{-1} ; \mathrm{CV}=10.9 \%\right)$} \\
\hline Annual & $4.9 \mathrm{~A}$ & $6.9 \mathrm{~A}$ & $9.9 \mathrm{~A}$ & $9.1 \mathrm{~A}$ & $15.6 \mathrm{~A}$ & $8.7 \mathrm{~A}$ & $12.0 \mathrm{~A}$ & $16.8 \mathrm{~A}$ & $13.9 \mathrm{~A}$ \\
\hline Biennial & $0.67 \mathrm{~B}$ & $1.3 \mathrm{~B}$ & $1.7 \mathrm{~B}$ & $4.0 \mathrm{~B}$ & $7.9 \mathrm{~B}$ & $3.3 \mathrm{~B}$ & $5.0 \mathrm{~B}$ & $6.2 \mathrm{~B}$ & 4.4B \\
\hline \multicolumn{10}{|c|}{ Phosphorus accumulation $\left(\mathrm{kg} \mathrm{ha}^{-1}\right.$ year $\left.^{-1} ; \mathrm{CV}=19.1 \%\right)$} \\
\hline Annual & $1.3 \mathrm{~A}$ & $3.9 \mathrm{~A}$ & $2.8 \mathrm{~A}$ & $3.5 \mathrm{~A}$ & $1.4 \mathrm{~A}$ & $0.73 \mathrm{~A}$ & $1.2 \mathrm{~A}$ & $1.5 \mathrm{~A}$ & $1.1 \mathrm{~A}$ \\
\hline Biennial & $0.13 \mathrm{~B}$ & $0.25 \mathrm{~B}$ & $0.49 \mathrm{~B}$ & $0.88 \mathrm{~B}$ & $0.94 \mathrm{~B}$ & $0.32 \mathrm{~B}$ & $0.69 \mathrm{~B}$ & $0.72 \mathrm{~B}$ & $0.62 \mathrm{~B}$ \\
\hline \multicolumn{10}{|c|}{ Phosphorus export $\left(\mathrm{kg} \mathrm{ha}^{-1} \mathrm{year}^{-1} ; \mathrm{CV}=20.8 \%\right)$} \\
\hline Annual & $0.29 \mathrm{~A}$ & $1.0 \mathrm{~A}$ & $1.3 \mathrm{~A}$ & $1.2 \mathrm{~A}$ & $0.46 \mathrm{~A}$ & $0.27 \mathrm{~A}$ & $0.47 \mathrm{~A}$ & $0.56 \mathrm{~A}$ & $0.41 \mathrm{~A}$ \\
\hline Biennial & $0.04 \mathrm{~B}$ & $0.10 \mathrm{~B}$ & $0.13 \mathrm{~B}$ & $0.31 \mathrm{~B}$ & $0.42 \mathrm{~B}$ & $0.16 \mathrm{~B}$ & $0.29 \mathrm{~B}$ & $0.44 \mathrm{~B}$ & $0.27 \mathrm{~B}$ \\
\hline \multicolumn{10}{|c|}{ Potassium accumulation $\left(\mathrm{kg} \mathrm{ha}^{-1}\right.$ year $\left.^{-1} ; \mathrm{CV}=15.7 \%\right)$} \\
\hline Annual & $68.7 \mathrm{~A}$ & $88.7 \mathrm{~A}$ & $66.2 \mathrm{~A}$ & $57.9 \mathrm{~A}$ & $105.8 \mathrm{~A}$ & $55.6 \mathrm{~A}$ & $72.4 \mathrm{~A}$ & $94.1 \mathrm{~A}$ & $92.4 \mathrm{~A}$ \\
\hline Biennial & $6.4 \mathrm{~B}$ & $10.5 \mathrm{~B}$ & $17.7 \mathrm{~B}$ & $33.1 \mathrm{~B}$ & $35.0 \mathrm{~B}$ & $19.5 \mathrm{~B}$ & $28.3 \mathrm{~B}$ & $24.5 B$ & $23.5 \mathrm{~B}$ \\
\hline \multicolumn{10}{|c|}{ Potassium export $\left(\mathrm{kg} \mathrm{ha}^{-1}\right.$ year $\left.^{-1} ; \mathrm{CV}=14.8 \%\right)$} \\
\hline Annual & $14.8 \mathrm{~A}$ & $23.1 \mathrm{~A}$ & $33.9 \mathrm{~A}$ & $19.8 \mathrm{~A}$ & $38.1 \mathrm{~A}$ & $21.0 \mathrm{~A}$ & $34.9 \mathrm{~A}$ & $34.8 \mathrm{~A}$ & $38.2 \mathrm{~A}$ \\
\hline Biennial & $2.0 \mathrm{~B}$ & $4.0 \mathrm{~B}$ & $4.8 \mathrm{~B}$ & $11.5 \mathrm{~B}$ & $15.6 \mathrm{~B}$ & $9.7 \mathrm{~B}$ & $12.1 \mathrm{~B}$ & $14.7 \mathrm{~B}$ & $10.1 \mathrm{~B}$ \\
\hline \multicolumn{10}{|c|}{ Calcium accumulation $\left(\mathrm{kg} \mathrm{ha}^{-1}\right.$ year $\left.^{-1} ; \mathrm{CV}=17.3 \%\right)$} \\
\hline Annual & $42.3 \mathrm{~A}$ & $54.6 \mathrm{~A}$ & $49.9 \mathrm{~A}$ & $54.3 \mathrm{~A}$ & 78.7A & $46.9 \mathrm{~A}$ & $58.6 \mathrm{~A}$ & $86.0 \mathrm{~A}$ & $66.5 \mathrm{~A}$ \\
\hline Biennial & $6.9 \mathrm{~B}$ & 11.5B & $17.8 \mathrm{~B}$ & $34.4 \mathrm{~B}$ & $42.5 \mathrm{~B}$ & $20.1 \mathrm{~B}$ & $30.8 \mathrm{~B}$ & 23.3B & $25.1 \mathrm{~B}$ \\
\hline \multicolumn{10}{|c|}{ Calcium export $\left(\mathrm{kg} \mathrm{ha}^{-1}\right.$ year $\left.^{-1} ; \mathrm{CV}=13.1 \%\right)$} \\
\hline Annual & $9.0 \mathrm{~A}$ & $14.2 \mathrm{~A}$ & $25.5 \mathrm{~A}$ & $18.6 \mathrm{~A}$ & $27.7 \mathrm{~A}$ & $17.4 \mathrm{~A}$ & $27.2 \mathrm{~A}$ & $31.8 \mathrm{~A}$ & $27.3 \mathrm{~A}$ \\
\hline Biennial & $2.2 \mathrm{~B}$ & $4.3 \mathrm{~B}$ & $4.9 \mathrm{~B}$ & $12.0 \mathrm{~B}$ & $19.0 \mathrm{~B}$ & $10.0 \mathrm{~B}$ & $13.2 \mathrm{~B}$ & $14.0 \mathrm{~B}$ & $10.8 \mathrm{~B}$ \\
\hline \multicolumn{10}{|c|}{ Magnesium accumulation $\left(\mathrm{kg} \mathrm{ha}^{-1}\right.$ year $\left.^{-1} ; \mathrm{CV}=14.8 \%\right)$} \\
\hline Annual & $16.1 \mathrm{~A}$ & $18.3 \mathrm{~A}$ & $14.6 \mathrm{~A}$ & $16.4 \mathrm{~A}$ & $27.6 \mathrm{~A}$ & $16.7 \mathrm{~A}$ & $20.8 \mathrm{~A}$ & $26.6 \mathrm{~A}$ & $19.9 \mathrm{~A}$ \\
\hline Biennial & $2.1 \mathrm{~B}$ & $3.2 \mathrm{~B}$ & $6.5 \mathrm{~B}$ & $11.5 \mathrm{~B}$ & $11.9 \mathrm{~B}$ & $6.0 \mathrm{~B}$ & $9.2 \mathrm{~B}$ & $7.7 \mathrm{~B}$ & $7.6 \mathrm{~B}$ \\
\hline \multicolumn{10}{|c|}{ Magnesium export (kg ha year $\left.^{-1} ; \mathrm{CV}=13.3 \%\right)$} \\
\hline Annual & $3.4 \mathrm{~A}$ & $4.7 \mathrm{~A}$ & $7.5 \mathrm{~A}$ & $5.5 \mathrm{~A}$ & $9.5 \mathrm{~A}$ & $6.2 \mathrm{~A}$ & $9.6 \mathrm{~A}$ & $9.8 \mathrm{~A}$ & $8.1 \mathrm{~A}$ \\
\hline Biennial & $0.66 \mathrm{~B}$ & $1.2 \mathrm{~B}$ & $1.8 \mathrm{~B}$ & $4.0 \mathrm{~B}$ & $5.4 \mathrm{~B}$ & $3.0 \mathrm{~B}$ & $3.9 \mathrm{~B}$ & $4.6 \mathrm{~B}$ & $3.3 \mathrm{~B}$ \\
\hline \multicolumn{10}{|c|}{ Sulfur accumulation $\left(\mathrm{kg} \mathrm{ha}^{-1}\right.$ year $\left.^{-1} ; \mathrm{CV}=17.1 \%\right)$} \\
\hline Annual & $6.4 \mathrm{~A}$ & $8.6 \mathrm{~A}$ & $8.9 \mathrm{~A}$ & $12.7 \mathrm{~B}$ & $18.7 \mathrm{~B}$ & $13.2 \mathrm{~A}$ & $18.0 \mathrm{~A}$ & $17.8 \mathrm{~A}$ & $15.3 \mathrm{~B}$ \\
\hline Biennial & $2.3 \mathrm{~B}$ & $4.7 \mathrm{~B}$ & $6.7 \mathrm{~B}$ & $18.5 \mathrm{~A}$ & $25.4 \mathrm{~A}$ & $12.0 \mathrm{~B}$ & 16.0B & 13.1B & $18.3 \mathrm{~A}$ \\
\hline \multicolumn{10}{|c|}{ Sulfur export $\left(\mathrm{kg} \mathrm{ha}^{-1}\right.$ year $\left.^{-1} ; \mathrm{CV}=17.9 \%\right)$} \\
\hline Annual & $1.4 \mathrm{~A}$ & $2.2 \mathrm{~A}$ & $4.3 \mathrm{~A}$ & $4.1 \mathrm{~B}$ & $5.2 \mathrm{~B}$ & $4.5 \mathrm{~B}$ & $6.1 \mathrm{~B}$ & $6.5 \mathrm{~B}$ & $5.8 \mathrm{~B}$ \\
\hline Biennial & $0.73 \mathrm{~A}$ & $1.8 \mathrm{~A}$ & $1.8 \mathrm{~B}$ & $6.4 \mathrm{~A}$ & $11.4 \mathrm{~A}$ & $6.0 \mathrm{~A}$ & $6.8 \mathrm{~A}$ & $7.8 \mathrm{~A}$ & $7.9 \mathrm{~A}$ \\
\hline
\end{tabular}

$\mathrm{HF}$ - harvest frequency; CV - coefficient of variation.

Means followed by different letters, within the combinations of nitrogen and phosphorus, in the same column, are significantly different by Scott-Knott test at $5 \%$ probability. 
of $\mathrm{P}$ alone at the lower levels under annual harvest may be an indirect result of fertilization in response to the direct effect of harvest management with annual cut, which greatly compromised the root system of cactus pear, especially the young roots under conditions of high water stress, in such a way that it influenced the accumulation and export of $\mathrm{Ca}$ because, as discussed by Mengel and Kirkby (2001), the uptake of this nutrient is done only by young roots. Under biennial harvest, in well-structured and stabilized plants, with a better consolidated root system and higher nutrient reserve in the tissues, $\mathrm{P}$ levels promoted an increase in $\mathrm{Ca}$ extraction by the cactus pear. It is worth mentioning that the higher $\mathrm{P}$ levels that caused a reduction in the accumulation and export of $\mathrm{Ca}$ may have precipitated $\mathrm{Ca}$ in the soil when reacting with the phosphates present in the higher levels of $\mathrm{P}$, influencing the availability of $\mathrm{Ca}^{2+}$ for the crop, resulting in lower absorption, with reduced accumulation and export of the nutrient.

By providing positive responses on the productive pattern of cactus pear, $\mathrm{N}$ fertilization promoted, to a certain extent, a point of maximum accumulation and export of $\mathrm{Mg}$. Nevertheless, $\mathrm{N}$ fertilization increased aerial biomass and possibly favored root development (Zúñiga-Tarango et al., 2009) and potentiated the photosynthetic and respiratory area

Table 6 - Accumulation and export of macronutrients by cactus pear according to harvest frequencies, for different combinations of nitrogen and phosphorus, in the region of Tejuçuoca

\begin{tabular}{|c|c|c|c|c|c|c|c|c|c|}
\hline \multirow{2}{*}{$\mathrm{HF}$} & \multicolumn{9}{|c|}{ Combinations of $\mathrm{N}$ and $\mathrm{P}_{2} \mathrm{O}_{5}\left(\mathrm{~kg} \mathrm{ha}^{-1}\right.$ year $\left.^{-1}\right)$} \\
\hline & $10 / 70$ & $70 / 10$ & $70 / 70$ & $70 / 130$ & $100 / 100$ & $130 / 70$ & $130 / 130$ & $130 / 190$ & $190 / 130$ \\
\hline \multicolumn{10}{|c|}{ Nitrogen accumulation $\left(\mathrm{kg} \mathrm{ha}^{-1}\right.$ year $\left.^{-1} ; \mathrm{CV}=8.5 \%\right)$} \\
\hline Annual & $54.1 \mathrm{~A}$ & $57.0 \mathrm{~B}$ & $80.4 \mathrm{~B}$ & $78.1 \mathrm{~B}$ & $65.3 \mathrm{~B}$ & 114.7B & $168.8 \mathrm{~A}$ & 118.1B & 101.0B \\
\hline Biennial & $49.7 \mathrm{~A}$ & $104.3 \mathrm{~A}$ & $133.2 \mathrm{~A}$ & $136.2 \mathrm{~A}$ & $119.7 \mathrm{~A}$ & $161.5 \mathrm{~A}$ & $142.5 B$ & $167.1 \mathrm{~A}$ & $192.6 \mathrm{~A}$ \\
\hline \multicolumn{10}{|c|}{ Nitrogen export $\left(\mathrm{kg} \mathrm{ha}^{-1}\right.$ year $\left.^{-1} ; \mathrm{CV}=9.3 \%\right)$} \\
\hline Annual & $27.3 \mathrm{~B}$ & $37.5 \mathrm{~B}$ & $53.4 \mathrm{~B}$ & $55.5 \mathrm{~B}$ & 47.0B & $80.1 \mathrm{~B}$ & $120.2 \mathrm{~A}$ & $77.7 \mathrm{~B}$ & $69.9 \mathrm{~B}$ \\
\hline Biennial & $39.7 \mathrm{~A}$ & $82.1 \mathrm{~A}$ & $102.3 \mathrm{~A}$ & $111.8 \mathrm{~A}$ & $108.0 \mathrm{~A}$ & $132.3 \mathrm{~A}$ & $112.5 \mathrm{~B}$ & $133.6 \mathrm{~A}$ & $166.1 \mathrm{~A}$ \\
\hline \multicolumn{10}{|c|}{ Phosphorus accumulation $\left(\mathrm{kg} \mathrm{ha}^{-1}\right.$ year $\left.^{-1} ; \mathrm{CV}=16.1 \%\right)$} \\
\hline Annual & $2.7 \mathrm{~B}$ & $2.2 \mathrm{~B}$ & $4.5 \mathrm{~B}$ & $3.9 \mathrm{~B}$ & $3.8 \mathrm{~A}$ & $6.4 \mathrm{~A}$ & $6.6 \mathrm{~A}$ & $3.9 \mathrm{~B}$ & $3.9 \mathrm{~B}$ \\
\hline Biennial & $3.3 \mathrm{~A}$ & $6.0 \mathrm{~A}$ & $6.5 \mathrm{~A}$ & $5.1 \mathrm{~A}$ & $2.9 \mathrm{~B}$ & $5.6 \mathrm{~B}$ & $4.3 \mathrm{~B}$ & $10.9 \mathrm{~A}$ & $15.4 \mathrm{~A}$ \\
\hline \multicolumn{10}{|c|}{ Phosphorus export $\left(\mathrm{kg} \mathrm{ha}^{-1}\right.$ year $\left.^{-1} ; \mathrm{CV}=15.8 \%\right)$} \\
\hline Annual & $1.3 \mathrm{~B}$ & $1.5 \mathrm{~B}$ & $3.0 \mathrm{~B}$ & $2.8 \mathrm{~B}$ & $2.7 \mathrm{~A}$ & $4.5 \mathrm{~A}$ & 4.7A & $2.5 \mathrm{~B}$ & $2.7 \mathrm{~B}$ \\
\hline Biennial & $2.5 \mathrm{~A}$ & 4.7A & $4.9 \mathrm{~A}$ & $4.2 \mathrm{~A}$ & $2.6 \mathrm{~A}$ & $4.5 \mathrm{~A}$ & $3.3 \mathrm{~B}$ & $8.7 \mathrm{~A}$ & $13.3 \mathrm{~A}$ \\
\hline \multicolumn{10}{|c|}{ Potassium accumulation $\left(\mathrm{kg} \mathrm{ha}^{-1}\right.$ year $\left.^{-1} ; \mathrm{CV}=12.1 \%\right)$} \\
\hline Annual & $90.2 \mathrm{~A}$ & $78.3 \mathrm{~B}$ & $150.6 \mathrm{~A}$ & $134.2 \mathrm{~B}$ & $122.1 \mathrm{~B}$ & 202.9B & $263.1 \mathrm{~A}$ & 144.3B & $156.4 \mathrm{~B}$ \\
\hline Biennial & $105.0 \mathrm{~A}$ & $184.4 \mathrm{~A}$ & $153.2 \mathrm{~A}$ & $208.4 \mathrm{~A}$ & $165.1 \mathrm{~A}$ & $220.0 \mathrm{~A}$ & $201.8 \mathrm{~B}$ & $186.3 \mathrm{~A}$ & $234.8 \mathrm{~A}$ \\
\hline \multicolumn{10}{|c|}{ Potassium export $\left(\mathrm{kg} \mathrm{ha}^{-1}\right.$ year $\left.^{-1} ; \mathrm{CV}=12.7 \%\right)$} \\
\hline Annual & $45.3 \mathrm{~B}$ & $52.0 \mathrm{~B}$ & $99.6 \mathrm{~B}$ & $96.2 \mathrm{~B}$ & $90.5 \mathrm{~B}$ & 149.7B & $190.1 \mathrm{~A}$ & $95.5 \mathrm{~B}$ & 109.9B \\
\hline Biennial & $83.7 \mathrm{~A}$ & $145.3 \mathrm{~A}$ & $117.4 \mathrm{~A}$ & $171.2 \mathrm{~A}$ & $149.0 \mathrm{~A}$ & $180.1 \mathrm{~A}$ & $159.3 \mathrm{~B}$ & $148.9 \mathrm{~A}$ & $202.3 \mathrm{~A}$ \\
\hline \multicolumn{10}{|c|}{ Calcium accumulation $\left(\mathrm{kg} \mathrm{ha}^{-1} \mathrm{year}^{-1} ; \mathrm{CV}=8.3 \%\right)$} \\
\hline Annual & 124.7A & $166.3 \mathrm{~A}$ & $182.0 \mathrm{~A}$ & $161.9 \mathrm{~A}$ & $145.3 \mathrm{~B}$ & $211.5 \mathrm{~A}$ & $312.7 \mathrm{~A}$ & $186.6 \mathrm{~A}$ & $148.3 \mathrm{~A}$ \\
\hline Biennial & $101.4 \mathrm{~B}$ & $154.2 \mathrm{~B}$ & $166.3 \mathrm{~B}$ & $157.4 \mathrm{~A}$ & $168.8 \mathrm{~A}$ & $183.7 \mathrm{~B}$ & $135.4 \mathrm{~B}$ & $105.3 \mathrm{~B}$ & $151.9 \mathrm{~A}$ \\
\hline \multicolumn{10}{|c|}{ Calcium export $\left(\mathrm{kg} \mathrm{ha}^{-1}\right.$ year $\left.^{-1} ; \mathrm{CV}=7.6 \%\right)$} \\
\hline Annual & $67.0 \mathrm{~B}$ & $113.8 \mathrm{~A}$ & $120.3 \mathrm{~B}$ & 117.4B & 107.7B & $153.8 \mathrm{~A}$ & $225.3 \mathrm{~A}$ & $123.4 \mathrm{~A}$ & $103.6 \mathrm{~B}$ \\
\hline Biennial & $81.2 \mathrm{~A}$ & $120.3 \mathrm{~A}$ & $127.8 \mathrm{~A}$ & $129.3 \mathrm{~A}$ & $152.3 \mathrm{~A}$ & $150.4 \mathrm{~A}$ & $107.1 \mathrm{~B}$ & $84.2 \mathrm{~B}$ & $130.7 \mathrm{~A}$ \\
\hline \multicolumn{10}{|c|}{ Magnesium accumulation $\left(\mathrm{kg} \mathrm{ha}^{-1}\right.$ year $\left.^{-1} ; \mathrm{CV}=11.9 \%\right)$} \\
\hline Annual & $44.1 \mathrm{~A}$ & $40.5 \mathrm{~B}$ & $54.2 \mathrm{~B}$ & 47.7B & $45.6 \mathrm{~B}$ & $67.6 \mathrm{~B}$ & 103.3B & $72.4 \mathrm{~B}$ & 47.8B \\
\hline Biennial & $53.9 \mathrm{~A}$ & $81.0 \mathrm{~A}$ & $92.9 \mathrm{~A}$ & $106.8 \mathrm{~A}$ & $88.6 \mathrm{~A}$ & $96.2 \mathrm{~A}$ & $107.7 \mathrm{~A}$ & $109.1 \mathrm{~A}$ & $149.8 \mathrm{~A}$ \\
\hline \multicolumn{10}{|c|}{ Magnesium export $\left(\mathrm{kg} \mathrm{ha}^{-1}\right.$ year $\left.^{-1} ; \mathrm{CV}=10.1 \%\right)$} \\
\hline Annual & $22.9 \mathrm{~B}$ & $27.1 \mathrm{~B}$ & $35.8 \mathrm{~B}$ & $34.1 \mathrm{~B}$ & $33.1 \mathrm{~B}$ & $47.6 \mathrm{~B}$ & $72.3 \mathrm{~B}$ & 46.6B & $33.3 \mathrm{~B}$ \\
\hline Biennial & $42.6 \mathrm{~A}$ & $63.5 \mathrm{~A}$ & $71.3 \mathrm{~A}$ & 87.7A & $80.0 \mathrm{~A}$ & $78.9 \mathrm{~A}$ & $85.1 \mathrm{~A}$ & $87.2 \mathrm{~A}$ & $129.3 \mathrm{~A}$ \\
\hline \multicolumn{10}{|c|}{ Sulfur accumulation $\left(\mathrm{kg} \mathrm{ha}^{-1}\right.$ year $\left.^{-1} ; \mathrm{CV}=11.1 \%\right)$} \\
\hline Annual & $67.0 \mathrm{~A}$ & $64.1 \mathrm{~B}$ & $94.7 \mathrm{~B}$ & $100.9 \mathrm{~B}$ & $85.8 \mathrm{~B}$ & $123.4 \mathrm{~B}$ & $117.8 \mathrm{~A}$ & $50.0 \mathrm{~B}$ & $66.6 \mathrm{~B}$ \\
\hline Biennial & $66.0 \mathrm{~A}$ & $110.2 \mathrm{~A}$ & $112.3 \mathrm{~A}$ & $128.9 \mathrm{~A}$ & $131.4 \mathrm{~A}$ & $138.3 \mathrm{~A}$ & $102.6 \mathrm{~B}$ & $132.2 \mathrm{~A}$ & $168.1 \mathrm{~A}$ \\
\hline \multicolumn{10}{|c|}{ Sulfur export $\left(\mathrm{kg} \mathrm{ha}^{-1}\right.$ year $\left.^{-1} ; \mathrm{CV}=11.4 \%\right)$} \\
\hline Annual & $36.1 \mathrm{~B}$ & $44.5 \mathrm{~B}$ & $62.4 \mathrm{~B}$ & $73.6 \mathrm{~B}$ & $63.8 \mathrm{~B}$ & $91.2 \mathrm{~B}$ & $84.9 \mathrm{~A}$ & $32.0 \mathrm{~B}$ & 46.4B \\
\hline Biennial & $52.5 \mathrm{~A}$ & $86.6 \mathrm{~A}$ & $85.6 \mathrm{~A}$ & $106.0 \mathrm{~A}$ & $118.6 \mathrm{~A}$ & $113.4 \mathrm{~A}$ & $81.2 \mathrm{~B}$ & $105.8 \mathrm{~A}$ & $144.7 \mathrm{~A}$ \\
\hline
\end{tabular}


of the crop, which, associated with the evaporative demand of the atmosphere (vapor pressure deficit), optimized the nutrient uptake capacity by increasing the flow of the soil solution to the root zone and by the expansion of the root system, favoring the ion-root contact.

Moreover, the $\mathrm{N}$ and $\mathrm{P}$ combination favored the productive performance of the cactus pear and, consequently, reflected an increase in the accumulation and export of $\mathrm{Mg}$. The beneficial effect of $\mathrm{P}$ fertilization on $\mathrm{Mg}$ uptake is related to the fact that $\mathrm{Mg}$ plays a key role in the transport of $\mathrm{P}$ in the biochemical processes of the plant, mainly in phosphorylated reactions (Oliveira et al., 2001).

The dynamics of accumulation and export of $\mathrm{S}$, as well as the other nutrients, demonstrated the direct relationship with the productive capacity of the cactus pear. Thus, the factors that promoted a positive effect on the yield of the crop also potentiated the extraction of nutrients, including $\mathrm{S}$, in which the results indicated the influence of fertilization associated with annual and biennial harvest frequencies.

Furthermore, regarding the accumulation and export of $\mathrm{S}$, it is important to emphasize the action of urea (nitrogen fertilizer used herein) as a source of $\mathrm{NH}_{4}^{+}$, which favors the absorption and consequent accumulation of $\mathrm{S}$ because, according to Tisdale et al. (1985), the uptake of $\mathrm{N}$ in the ammoniacal form $\left(\mathrm{NH}_{4}^{+}\right)$can stimulate the absorption of $\mathrm{S}\left(\mathrm{SO}_{4}{ }^{2-}\right)$.

The pattern of accumulation and export of $\mathrm{N}$ in the two harvest frequencies in both regions resulted from the dynamics of biomass production in the two regions, altering the order of superiority between the harvest managements.

With respect to the differences found for the accumulation and export of $\mathrm{P}$ under the two harvest frequencies, for Quixadá and Tejuçuoca conditions, as mentioned for the accumulation and export of $\mathrm{N}$, these are results of the differentiated pattern of biomass accumulation in each cultivation condition in the two harvesting frequencies. This is a reflection of fluctuations in crop growth throughout the development cycle, which is closely related to the environment and management conditions.

The distinct accumulation and export of $\mathrm{K}$ and $\mathrm{Ca}$ between the harvesting frequencies, in Quixadá and Tejuçuoca, with higher values either for annual or biennial harvest, were due to the variations in the production of forage biomass, associated with the contents of these nutrients in the tissues of cactus pear cladodes.

The dynamics of cactus pear response in terms of accumulation and export of $\mathrm{Mg}$ and $\mathrm{S}$ under annual and biennial harvest frequencies, in Quixadá and Tejuçuoca regions, can be attributed to the same reasons previously described in the scope of this study for the other macronutrients.

\section{Conclusions}

In Quixadá, under management of annual harvest frequency and fertilization with combined levels of $\mathrm{N}$ and $\mathrm{P}$ for maximum biological response in terms of biomass production, the cactus pear exhibits the following decreasing order of accumulation of macronutrients: $\mathrm{K}>\mathrm{Ca}>\mathrm{N}>$ $\mathrm{Mg}>\mathrm{S}>\mathrm{P}$. Under biennial harvest, the decreasing order of accumulation is $\mathrm{Ca}>\mathrm{K}>\mathrm{S}>\mathrm{N}>\mathrm{Mg}>\mathrm{P}$.

In Tejuçuoca, with annual harvest frequency and fertilization with combined levels of $\mathrm{N}$ and $\mathrm{P}$ for maximum biomass production, the cactus pear shows the following decreasing order of accumulation of macronutrients: $\mathrm{K}>$ $\mathrm{Ca}>\mathrm{N}>\mathrm{Mg}>\mathrm{S}>\mathrm{P}$. Under biennial harvest, it presents the following decreasing order of accumulation: $\mathrm{K}>\mathrm{N}>\mathrm{S}>$ $\mathrm{Ca}>\mathrm{Mg}>\mathrm{P}$.

The maintenance/production fertilization in cactus pear should be planned according to productive potential, fertilization and harvest managements, and cultivation region, based on nutritional requirement and considering the nutrient recovery efficiency.

\section{Acknowledgments}

The authors thank Banco do Nordeste (BNB), for funding this research project.

\section{References}

Alves, R. N.; Farias, I.; Menezes, C. R. S.; Lira, M. A. and Santos, C. D. 2007. Produção de forragem pela palma após 19 anos sob diferentes intensidades de corte e espaçamentos. Revista Caatinga 2:38-44.

Bonfim-Silva, E. M.; Guimarães, S. L.; Farias, L. N.; Oliveira, J. R.; Bosa, C. K. and Fontenelli, J. V. 2014. Adubação fosfatada no desenvolvimento e produção de feijão guandu em latossolo vermelho do cerrado em primeiro cultivo. Bioscience Journal 30:1380-1388.

Bonfim-Silva, E. M.; Silva, T. J.; Cabral, C. E. A.; Gonçalves, J. M. and Pereira, M. T. J. 2011. Produção e morfologia da leguminosa java submetida a adubação fosfatada. Enciclopédia Biosfera 7:1-10.

Cavalcante, L. A. D.; Santos, G. R. A.; Silva, L. M.; Fagundes, J. L. and Silva, M. A. 2014. Respostas de genótipos de palma forrageira a diferentes densidades de cultivo. Pesquisa Agropecuária Tropical 44:424-433.

Costa, K. A. P.; Faquin, V.; Oliveira, I. P.; Rodrigues, C. and Severiano, E. C. 2008. Doses e fontes de nitrogênio em pastagem de capim-marandu. I - Alterações nas características químicas do solo. Revista Brasileira de Ciência do Solo 32:1591-1599. 
Dubeux Jr, J. C. B.; Araújo Filho, J. T.; Santos, M. V. F.; Lira, M. A.; Santos, D. C. and Pessoa, R. A. S. 2010. Adubação mineral no crescimento e composição mineral da palma forrageira - Clone IPA-20. Revista Brasileira de Ciências Agrárias 5:129-135.

Lopes, E. B.; Albuquerque, I. C.; Brito, C. H. and Batista, J. L. 2009. Efeito do período de cura de cladódios da palma gigante na emissão de raízes em Neossolo no Município de Lagoa Seca, Paraíba, Brasil. Revista Engenharia Ambiental 6:231-239.

Malavolta, E.; Gomes, F. P. and Alcarde, J. C. 2006. Adubos e adubações. Nobel, São Paulo.

Mengel, K. and Kirkby, E. A. 2001. Principles of plant nutrition. Kluwer Academic Publishers, Dordrechth.

Nobel, P. S.; Russell, C. E.; Felker, P.; Medina, J. G. and Acunã, E. 1987. Nutrient relations and productivity of prickly pear cacti. Agronomy Journal 79:550-555.

Oliveira, I. P.; Edwards, D. G.; Asher, C. J.; Grundon, N. J.; Santos, R. S. M. and Faria, C. D. 2001. Modos de aplicação e doses de fósforo no crescimento do feijoeiro. Pesquisa Agropecuária Tropical 31:1-5.
Silva, C. 2009. Manual de análises químicas de solos, plantas e fertilizantes. 2.ed. rev. ampl. Brasília, DF.

Silva, J. A.; Bonomo, P.; Donato; S. L. R.; Pires, A. J. V.; Rosa, R. C. C. and Donato, P. E. R. 2012. Composição mineral em cladódios de palma forrageira sob diferentes espaçamentos e adubações química. Revista Brasileira de Ciências Agrárias 7:866-875.

Souto, J. S.; Oliveira, F. T.; Gomes, M. M. S.; Nascimento, J. P. and Souto, P. C. 2009. Efeito da aplicação de fósforo no desenvolvimento de planta de feijão guandu (Cajanus cajan (L) Millsp). Revista Verde 4:135-140.

Tisdale, S. L.; Beaton, J. D. and Nelson, W. L. 1985. Soil fertility and fertilizers. 4th ed. MacMillan, New York.

Zúñiga-Tarango, R.; Orona-Castillo, I.; Vázquez-Vázquez, C.; Murillo-Amador, B.; Salazar-Sosa, E.; López-Martínez, J. D.; García-Hernández, J. L. and Rueda-Puente, E. 2009. Desarrollo radical, rendimiento y concentración mineral en nopal Opuntia ficus-indica (L.) Mill. en diferentes tratamientos de fertilización. Journal of the Professional Association for Cactus Development 11:53-68. 